\title{
"Digital and economic transformations for sustainable development promotion: A case of OECD countries"
}

\begin{tabular}{|c|c|}
\hline \multirow{5}{*}{ AUTHORS } & Leonid Melnyk (iD) \\
\hline & Oleksandr Kubatko (i) \\
\hline & Vladyslav Piven \\
\hline & Kyrylo Klymenko (iD) \\
\hline & Larysa Rybina (iD) \\
\hline ARTICLE INFO & $\begin{array}{l}\text { Leonid Melnyk, Oleksandr Kubatko, Vladyslav Piven, Kyrylo Klymenko and } \\
\text { Larysa Rybina (2021). Digital and economic transformations for sustainable } \\
\text { development promotion: A case of OECD countries. Environmental Economics, } \\
\text { 12(1), 140-148. doi:10.21511/ee.12(1).2021.12 }\end{array}$ \\
\hline DOI & http://dx.doi.org/10.21511/ee.12(1).2021.12 \\
\hline RELEASED ON & Tuesday, 04 January 2022 \\
\hline RECEIVED ON & Monday, 11 October 2021 \\
\hline \multirow[t]{2}{*}{ ACCEPTED ON } & Monday, 20 December 2021 \\
\hline & $(\mathrm{cc}) \mathrm{EY}$ \\
\hline LICENSE & $\begin{array}{l}\text { This work is licensed under a Creative Commons Attribution } 4.0 \text { International } \\
\text { License }\end{array}$ \\
\hline JOURNAL & "Environmental Economics" \\
\hline ISSN PRINT & $1998-6041$ \\
\hline ISSN ONLINE & $1998-605 x$ \\
\hline PUBLISHER & LLC "Consulting Publishing Company "Business Perspectives" \\
\hline FOUNDER & LLC "Consulting Publishing Company "Business Perspectives" \\
\hline
\end{tabular}

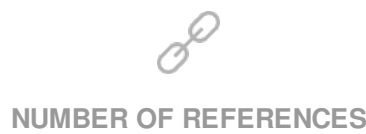

33

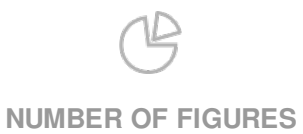

0

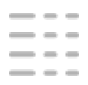

NUMBER OF TABLES

2

(C) The author(s) 2022. This publication is an open access article. 


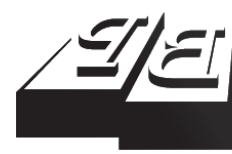

\section{BUSINESS PERSPECTIVES}

LLC "CPC "Business Perspectives" Hryhorii Skovoroda lane, 10, Sumy, 40022, Ukraine www.businessperspectives.org
Received on: $11^{\text {th }}$ of October, 2021 Accepted on: $20^{\text {th }}$ of December, 2021 Published on: $4^{\text {th }}$ of January, 2022

(c) Leonid Melnyk, Oleksandr Kubatko, Vladyslav Piven, Kyrylo Klymenko, Larysa Rybina, 2022

Leonid Melnyk, Doctor of Economics, Department of Economics, Entrepreneurship and Business Administration, Sumy State University, Ukraine.

Oleksandr Kubatko, Doctor of Economics, Department of Economics, Entrepreneurship and Business Administration, Sumy State University, Ukraine. (Corresponding author)

Vladyslav Piven, Researcher, Department of Economics, Entrepreneurship and Business Administration, Sumy State University, Ukraine.

Kyrylo Klymenko, Ph.D. in Law, National University of Life and Environmental Sciences Kyiv, Ukraine.

Larysa Rybina, Candidate of Economic Sciences, Associate Professor, Sumy National Agrarian University, Ukraine.

This is an Open Access article, distributed under the terms of the Creative Commons Attribution 4.0 International license, which permits unrestricted re-use, distribution, and reproduction in any medium, provided the original work is properly cited.

Conflict of interest statement: Author(s) reported no conflict of interest

Leonid Melnyk (Ukraine), Oleksandr Kubatko (Ukraine), Vladyslav Piven (Ukraine), Kyrylo Klymenko (Ukraine), Larysa Rybina (Ukraine)

\title{
DIGITAL AND ECONOMIC TRANSFORMATIONS FOR SUSTAINABLE DEVELOPMENT PROMOTION: A CASE OF OECD COUNTRIES
}

\begin{abstract}
Digitalization, dematerialization of production and consumption, and structural shifts in the direction of service economy forming do promote to reduction of material use and sustainable development. The paper aims to investigate the role of digital, structural, economic, and social factors in sustainable development promotion in OECD countries. The paper uses the data on digital achievements, social and economic development of OECD member states from World Bank data sources for the period 2007-2018. The randomeffects GLS regression model is used, and empirical regression models to estimate the influence of key factors related to digital transformation on GDP per capita and CO2 emissions per capita are constructed. The results of the regression analysis show that using the number of Internet users as an indicator for achievement in digitalization has a positive and statistically significant influence on GDP per capita due to lower transaction costs and higher share service economy. An increase in urbanization rates (as an indicator of capital concentrations and labor specialization) by one percent promotes a GDP per capita increase of 299 USD. Also, an increase in Gini coefficient by one percentage point correlates with decrease in GDP per capita on 196 USD and the reduction of CO2 per capita by 0.12 tones due to the structural shifts in aggregate demand. Still, improvements in digital transformations have no significant environmental effect in OECD members, while processes related to urbanization, income inequality, and share of industrial output are important drivers for $\mathrm{CO} 2$ per capita reduction.
\end{abstract}

Keywords

JEL Classification

\section{INTRODUCTION}

The transition to sustainable development in modern conditions is difficult to implement without the digital transformation of the global economy. In 2015, the UN General Assembly approved 17 Sustainable Development Goals, which include the implementation of 169 targets and 304 indicators (United Nations, n.d.a). These goals are global and universal, and their implementation will contribute to the promotion of sustainable development in different countries. Digital transformations and dematerialization of production and consumption indirectly affect all Sustainable Development Goals through the reduction of material production inputs. The main technologies that provide digitalization of various spheres of public life are virtual and augmented reality, additive technologies, artificial intelligence, blockchain, the Internet of Things, and others. The World Bank also emphasizes the importance of digital transformation for economic growth, new jobs, services, since the last help businesses to be more productive, people can easier find jobs/expand their capabilities, and governments can provide better public services to all citizens (The World Bank, n.d.a, n.d.b). 
The relations between digital transformations and sustainable development are not so unambiguous. On the one hand, digitalization positively contributes to sustainability through the dematerialization of production and consumption. On the other hand, digital transformations can cause negative effects on economic, social, and environmental development. Therefore, all these aspects need further research to promote sustainable development more effectively.

\section{LITERATURE REVIEW}

To remain competitive in the digital age, businesses need new approaches and good practices for innovative development as a key aspect of a business. A survey conducted by McKinsey \& Company demonstrates the impact of the COVID-19 pandemic on the implementation of digital technologies in the business processes of enterprises around the world. Thus, during the pandemic, consumers began to use digital applications much more to buy goods and services. Global indicators of the number of interactions between companies and customers through online communication increased from $36 \%$ in 2019 to $58 \%$ in 2020 . There is a similar indicator that demonstrates the role of lockdown restrictions on the number of goods and services that have been partially or fully digitized. In addition, most employees of enterprises that have digitized the provision of goods and services are confident that digital transformations (remote work, communication with customers through online communication, the introduction of high technology) will not be levelled even after the pandemic of COVID-19 (McKinsey \& Company, 2020). In turn, the European Central Bank conducted a survey of 74 large non-financial companies, half of which produced goods, others were service providers to find out which digital technologies are used by large European companies to do business, the similar results were discussed by Kartanaite et al. (2021). The results showed that most of the surveyed companies use different digital technologies, among which the leading are big data analysis (87\%) and cloud storage $(82 \%)$. In the B2C segment, e-commerce technologies are widely used. Industrial enterprises also use artificial intelligence, the Internet of Things, robotics, and 3D printing (European Central Bank, 2021). By the way, 3D printers are the main tool for the implementation of additive production. 3D printers have a number of advantages that increase their importance for today's economy. First of all, they can be used to create and print any product, which will avoid significant logistics costs (including delivery and storage), packaging costs. Secondly, additive technologies (as opposed to substrate ones) allow production of products in a qualitatively new way without the need to combine individual details into a single whole. One of the largest industries where 3D printers are already used is the car industry (they mostly print gearboxes and door handles). However, there are companies that already have the technology to print car bodies. There are various assessments of the impact of additive technologies on the world economy in general and energy in particular. Thus, according to Gobler et al. (2014), the use of 3D printers will reduce global energy consumption by 2.54-9.3 EJ and CO2 emissions by $130.5-525.5 \mathrm{Mt}$ by 2025. Additive technologies clearly demonstrate one of the most important advantages of digitalization - dematerialization of the global economy, which can lead to significant opportunities (less $\mathrm{CO} 2$ emissions and, as a result, climate change mitigation).

Different scientists have studied the relationship between digitalization and sustainable development. Thus, Bhutani and Palival (2015) formulated the model " $5 \mathrm{Cs}$ of Inclusive Sustainable Growth", the essence of which was to characterize the digital technologies needed for the transition to sustainable development. Positive effects of digitalization were also emphasized: better living conditions, active public participation, dynamic urban development, transparent governance, etc., which will contribute to the formation of a conscious, competitive personality that will become an "agent of change" towards sustainable development. Jovanović et al. (2018) assessed the available tools for analyzing the level of digitalization of the country (in particular, special indexes published by international organizations). They noted that digitalization is an impetus for the transformation of economic processes at a micro- and macro-level.

There are different approaches to measuring digital transformations and their impact on sustainability. For example, there is the Digital Economy 
and Society Index (DESI), which is published annually by the European Commission (European Commission, 2021). This index summarizes the digitalization indicators of the European Union member states and helps to track the progress of these countries in digital transformations. The rating methodology is to assess five aggregate indicators:

1. Communication (fixed and mobile communication and the availability of prices for them).

2. Human capital (use of the Internet, development of basic and advanced digital skills).

3. Use of Internet services (use of search engines, messengers, etc).

4. Integration of digital technologies (digitalization of business, e-commerce).

5. Digital public services (e-government, e-health).

After the evaluation of each of the indicators, the total indicator of this index is calculated according to the formula, where $b_{i}$ is the evaluation for the $i$-th indicator, $c_{i}$ is the weight coefficient of each of the $i$-th indicators:

$$
D E S I=\sum_{1}^{5} b_{i} c_{i} .
$$

Sustainable development is a complex process, which includes economic, social, and environmental parts. Innovative technologies are a key driver of economic growth in countries and regions. Technological progress allows to organize production more efficiently and produce better goods and services (Ruihui et al., 2021). Zhang et al. (2021) studied the impact of digital infrastructure and digital integration on the overall productivity of some regions in China and found it to be positive and statistically significant. Social development is one of the most important functions of the state, which is provided, in particular, by economic growth. The social, economic, cultural effects of disruptive industrial technologies as well as energy-efficient transformation for sustainability were studied by Sineviciene et al. (2021), Karintseva et al. (2021), Klymchuk et al. (2020), and Grytten et al. (2020). The impact of digitali- zation on the social development of the country is complex, which clearly illustrates the creation of new digital jobs. Thus, Balsmeier and Woerter (2019) showed that investment in digital technology increases the number of jobs for highly skilled workers and reduces the number of such jobs for unskilled employees.

Digital transformations can provide a rapidly growing population with access to health care, education, and banking. As the number of people living below the poverty line decreases and the simplest electronic devices become cheaper, ICTs become available to people in the least developed countries. By 2030, digitalization will provide access to e-health for 1.6 billion people, attract almost 450 million to e-learning, and save 254 billion hours for workers in various sectors of the economy (GeSI, n.d.). Veklych et al. (2020) and Melnyk et al. (2019) studied the transition of digital economies towards sustainability. Innovative strategies to increase economic efficiency and renewable energy development are covered by Kurbatova et al. (2020), Melnyk et al. (2013), and Shkarupa et al. (2017).

According to the concept developed by the Organization for Economic Cooperation and Development, the impact of digital transformations on the environment can be divided into the following categories (OECD, 2019):

Direct (first-order effect) - includes the direct use of natural resources and emissions caused by the production, use, and disposal of ICT goods.

- Indirect (second-order effect) - includes the use of digital technologies to increase the efficiency of resource use in production (through the optimization of production capacity and automation of business processes).

- Systemic (third-order effect) - includes changes in the behavior of economic entities and other non-technological factors due to the trend towards the introduction of digital technologies (Melnyk, 2021). A systemic impact of digital transformations is mostly considered to be promising, but its results have a significant time lag. 
It should be noted that the division of effects into the first, second, and third orders is quite conditional, as each of them can have a significant impact on the environment. Based on the literature review, the relevance of such a study is quite high, and it requires further research.

The aim of the study is to investigate the role digital, structural, economic and social factors in sustainable development promotion in OECD countries.

\section{METHODOLOGY AND DATA DESCRIPTION}

The paper uses the data from the World Bank about all OECD member states (The World Bank, n.d.a, n.d.b). There were several gaps in data for some specific states, which were filled by linear approximation from the existing data for that state. In addition, there were no available data for income inequality for New Zealand, and that state was not included in the list. That is the final balanced data contains information on 37 OECD member states' economies.

Digitalization is a complex process, which can be characterized by many indicators. As it was mentioned, there are certain indexes, which have the aim to describe the quality of digital transformations. However, some of these indexes concern a limited number of countries (for example, DESI summarizes the digitization indicators only of the European Union member states), others have an imperfect methodology or describe only a certain aspect of digitalization (for example, e-governance). The World Bank gives information about different digital indicators, and this paper uses some of them, including the number of Internet users among the total population, the share of ICT in the overall structure of exports, the share of hightech exports in the overall structure of exports. The number of Internet users among the total population demonstrates not only the level of the population access to the Internet but is mainly treated as an econometric instrument for achievement in digitalization and reduction of transaction costs. In fact, it is not the number of Internet users that could improve the GDP indicators, but the related process of post-industrial economy forming.
According to SDG 9, governments should significantly expand access to information and communications technologies and put efforts to provide universal and affordable access to the Internet. The share of ICT and high-tech exports in the overall structure of exports are supposed to promote the formation of post-industrial sectors, which reduces the degree of $\mathrm{CO} 2$ emissions. Besides, high-tech export and investment in R\&D is expected to provide high added value, which has a positive impact on GDP (Benetyte et al., 2021)

GDP per capita in constant prices is considered to be one of the best ways to describe the level of economic development of a state. Therefore, it is used as a dependent variable in the first regression model. The second regression model uses $\mathrm{CO} 2$ emissions per capita as a dependent variable. $\mathrm{CO} 2$ emissions are a global threat to the environment because of their impact on climate change. Though there are many other indicators to characterize the state of the environment, $\mathrm{CO} 2$ emissions per capita are one of the most widely used.

To diversify the regression models and to upset the omitted variable bias, several other non-digital indicators were also included. They are a share of the urban population; the amount of foreign direct investment (in \% of GDP) and the Gini index. Actually, it is expected that it is not urbanization itself but related capital concentrations specialization of the labor force are positive drivers of economic growth and improvement of the environmental situation.

In the second regression model with $\mathrm{CO} 2$ per capita as a dependent variable, it additionally uses such explanatory variables as the share of value-added services in GDP (in \%) and the share of value-added of industry in GDP (in \%). Both economic and environmental models include an institutional dummy variable - the membership in the European Union. The EU is an organization with a common energy strategy, which is reflected in EU energy union reports (Shevchenko et al., 2021). Thus, it is important to research what impact the membership in the EU has on the amount of $\mathrm{CO} 2$ emissions per capita.

The description of the first regression model is as follows: 


$$
\begin{aligned}
& G D P_{t}=F\left(i u_{t}, i e_{t}, h t e_{t}, r d_{t},\right. \\
& \left.u p_{t}, f d i_{t}, \operatorname{gin}_{t}, e u_{t}\right) \text {, }
\end{aligned}
$$

where the dependent variable is $G D P_{t}$ (GDP per capita (at constant prices)). Independent variables include: $\mathrm{iiu}_{t}$ - the number of Internet users among the total population (in \%); $i e_{t}$ - the share of ICT in the overall structure of exports (in \%); $h t e_{t}$ - the share of high-tech exports in the overall structure of exports (in \%); $r d_{t}$ - research and development expenditures are a share of GDP (in \%); $u p_{t}$ - share of urban population (in \%); $f d i_{+}$- amount of foreign direct investment (in \% of GDP); gin is the Gini index; $e u_{t}$ - the institutional dummy variable - EU membership (1 - EU member, 0 - non-EU member).

The next regression model is described as:

$$
\begin{aligned}
& C O 2 t=F\left(g d p_{t}, i i u_{t}, i e_{t}, h t e_{t}, r d_{t},\right. \\
& \left.s v a_{t}, i v a_{t}, u p_{t}, f d i_{t}, g i n_{t}, e u_{t}\right),
\end{aligned}
$$

where the dependent variable is $\mathrm{CO} 2 t$ (the amount of $\mathrm{CO} 2$ emissions per capita in metric tons). Independent variables include: $g d p_{t}, i u_{t}, i e_{t}, h t e_{t}, u p_{t}$, $f d i_{t}, g i i_{t}$, and $e u_{t}$ as expained in GDP model above.; $s v a_{t}$ - share of value-added services in GDP (in \%); $i v a_{t}$ - share of value-added of industry in GDP (in \%).

\section{RESULTS AND DISCUSSION}

Having discussed the methodology and described the data, it is necessary to build a proper econometric model for estimating the relevant economic and environmental effects of processes related to digital transformations. The results of such an assessment are shown in Table 1.

The results of the regression analysis demonstrate that the number of Internet users, as an econometric instrument for achievement in digitalization and reduction of transaction costs, has a positive and statistically significant impact on GDP per capita. Thus, with an increase in Internet users by 1\%, GDP per capita increases by an average of 69.73 USD. In addition, the share of ICT and high-tech exports in its overall structure has a positive effect on GDP per capita, but this impact is statistically insignificant. Price Waterhouse Coopers (2013) obtained similar results. Thus, their analysis showed that with the growth of digitalization in the country by 10 points (calculated according to the $\mathrm{PwC}$ methodology), GDP per capita increases by $0.75 \%$, and unemployment on average falls by $1.02 \%$. In addition, if emerging economies can double the level of digitalization, it will lead to an overall increase in world GDP of USD 4.4 trillion, an additional USD 930 billion in cumulative income, and an additional 64 million jobs for the people with low income.

The foreign direct investments are appeared to be an insignificant factor, while an increase in urbanization rates by one percent leads to a GDP per capita increase of 299 USD, which means that urbanization and related capital concentrations positive drivers of economic growth. Also, an increase in the Gini coefficient by one percentage point lead

\begin{tabular}{|c|c|c|c|c|c|c|}
\hline \multicolumn{4}{|c|}{$\begin{array}{l}\text { Random-effects GLS regression } \\
\text { Group variable: id } \\
\text { R-sq: } \text { within }=0.1262 \\
\text { between }=0.2837 \\
\text { overall }=0.2771 \\
\text { Wald chi2 }(8)=66.80 \\
\text { corr }\left(u \_i, X\right)=0 \text { (assumed) }\end{array}$} & \multicolumn{3}{|c|}{$\begin{array}{l}\text { Number of obs }=444 \\
\text { Number of groups }=37 \text { Obs per group: } \\
\min =12 \\
\operatorname{avg}=12.0 \\
\max =12 \\
\text { Prob. }>\text { chi } 2=0.0000\end{array}$} \\
\hline gdp & Coef. & Std. err. & $\mathbf{z}$ & $P>|z|$ & [95\% Conf. & Interval] \\
\hline iiu & 69.73237 & 17.61761 & 3.96 & 0.000 & 35.20249 & 104.2623 \\
\hline ie & 72.09732 & 51.80319 & 1.39 & 0.164 & -29.43507 & 173.6297 \\
\hline ht & .2285991 & .3181223 & 0.72 & 0.472 & -.3949091 & .8521073 \\
\hline rd & -442.504 & 547.212 & -0.81 & 0.419 & -1515.02 & 630.0118 \\
\hline up & 299.7267 & 131.7965 & 2.27 & 0.023 & 41.4103 & 558.0432 \\
\hline fdi & -13.04004 & 10.94944 & -1.19 & 0.234 & -34.50055 & 8.420477 \\
\hline $\operatorname{gin}$ & -196.6199 & 100.698 & -1.95 & 0.051 & -393.9843 & .7445448 \\
\hline $\mathrm{eu}$ & $-2,736.184$ & $4,722.086$ & -0.58 & 0.562 & $-11,991.3$ & $6,518.934$ \\
\hline Cons & $15,005.01$ & $11,259.05$ & 1.33 & 0.183 & -7062.331 & $37,072.34$ \\
\hline
\end{tabular}
to a decrease in GDP by 196 USD per capita, due to the structural shifts in aggregate demand.

Table 1. Impact of digital factors on GDP per capita (in constant prices) 
Table 2. Impact of digital factors on $\mathrm{CO} 2$ emissions per capita

Source: Authors' calculations performed using Stata 16.0.

\begin{tabular}{|c|c|c|c|c|c|c|}
\hline \multicolumn{4}{|c|}{$\begin{array}{l}\text { Random-effects GLS regression } \\
\text { Group variable: id } \\
\text { R-sq: } \text { within }=0.1977 \\
\text { between }=0.004 \\
\text { overall }=0.002 \\
\text { Wald chi2 }(8)=79.86 \\
\text { corr }\left(u_{\text {_i }} \text {, X) }=0 \text { (assumed) }\right.\end{array}$} & \multicolumn{3}{|c|}{$\begin{array}{l}\text { Number of obs }=444 \\
\text { Number of groups }=37 \\
\text { Obs per group: } \\
\min =12 \\
\operatorname{avg}=12.0 \\
\max =12 \\
\text { Prob. }>\text { chi } 2=0.0000\end{array}$} \\
\hline $\operatorname{co2}$ & Coef. & Std. err. & $z$ & $P>|z|$ & [95\% Conf. & Interval] \\
\hline ie & .0215052 & .0185042 & 1.16 & 0.245 & -.0147624 & .0577728 \\
\hline ht & -.0001307 & .0001145 & -1.14 & 0.254 & -.0003551 & .0000937 \\
\hline rd & .3235669 & .1895172 & 1.71 & 0.088 & -.0478799 & .6950137 \\
\hline sva & .0017258 & .0577438 & 0.03 & 0.976 & -.11145 & .1149016 \\
\hline iva & .1166888 & .053321 & 2.19 & 0.029 & .0121815 & .2211962 \\
\hline up & -.1409351 & 0378489 & -3.72 & 0.000 & -.2151176 & -.0667526 \\
\hline fdi & .0022566 & .0039558 & 0.57 & 0.568 & -.0054966 & .0100097 \\
\hline $\operatorname{gin}$ & -.1238433 & .0342205 & -3.62 & 0.000 & -.1909143 & -.0567723 \\
\hline $\mathrm{eu}$ & -2.00937 & 1.330414 & -1.51 & 0.131 & -4.616934 & .5981945 \\
\hline _cons & 20.35112 & 5.747713 & 3.54 & 0.000 & 9.085806 & 31.61643 \\
\hline
\end{tabular}

In addition, among the non-digital factors, the share of the urban population has a statistically significant and positive impact on GDP per capita.

The results of the regression analysis show that a statistically significant effect on $\mathrm{CO} 2$ emissions per capita has the improvement in digital transformations (both using the indicator of Internet users and share of high-tech exports) and statistically insignificant effect on $\mathrm{CO} 2$ emissions.

In addition, among the non-digital factors, the Gini index has a statistically significant effect on $\mathrm{CO} 2$ emissions, and an increase in the Gini coefficient by one percentage point leads to a decrease in $\mathrm{CO} 2$ per capita on 0.12 tons per capita. The inequality increases lead to carbon dioxide emissions decreasing due to the unequal consumption of energy resources. The improvements in achievements related to urbanization lead to $\mathrm{CO} 2$ per capita emissions decrease.

The institutional variable showed that EU membership has a statistically insignificant impact on $\mathrm{CO} 2$ emissions. This result is different from Kahouli (2019), who outlined that OECD EU countries have better environmental performance than non-EU OECD members.

According to the results of the study, the main task for policy-makers is to promote digital transformations for the economic growth. It was proved that digitalization has a positive impact on the econom- ic, but not on the environmental success of a country. Certain recommendations for policy-makers are suggested:

- it is highly recommended to provide the access to the Internet to all groups of the population. This can be successfully implemented by collaboration with private companies (Internet providers);

- it is important to expand mobile communication network by creating governmental programs;

- it is up to the governments to stimulate innovations by using policy mechanisms. For example, policy-makers should provide certain fiscal incentives (tax subsidies, grants) for high-technological companies, provide the rule of law in the sphere of intellectual property rights, procure more innovative goods and services (Makarenko et al., 2021);

- the development of e-governance should become a priority for governments. Providing a wide range of services on the Internet (including starting a business, taxes payment, elements of digital democracy) will significantly contribute to sustainability;

it is crucial to improve the system of education and science in the context of STEM education to foster talents. 


\section{CONCLUSIONS}

Digital transformations are an important tool for implementing the transition to sustainable development, in particular through the Sustainable Development Goals. The impact of digitalization on the economic and environmental development of the OECD member states proves the efficiency of investing in digitalization to promote economic growth. Therefore, the results of the regression analysis show that the number of Internet users among the total population has a positive and statistically significant correlates on the GDP per capita. When the number of Internet users increases by $1 \%$, GDP per capita increases by an average of 69.73 USD. In addition, the share of ICT and high-tech exports in its overall structure has a positive effect on GDP per capita, but this link is statistically insignificant. The number of Internet users among the total population has a statistically insignificant effect on $\mathrm{CO} 2$ emissions per capita. On the contrary, the processes related to the promotion of urbanization, reducing income inequality, and reducing the share of industrial output are important drivers for $\mathrm{CO} 2$ per capita reduction.

In addition, the reduction in $\mathrm{CO} 2$ emissions is influenced by the increase in the share of hightech exports in the overall structure of exports, but these relations are statistically insignificant. The institutional variable showed that EU membership has statistically insignificant relations with GDP per capita and $\mathrm{CO} 2$ emissions per capita. The main conclusion is that digital transformations contribute to the dematerialization of economic systems, promote economic growth, but do not stimulate $\mathrm{CO} 2$ reduction.

\section{AUTHOR CONTRIBUTIONS}

Conceptualization: Leonid Melnyk.

Data curation: Vladyslav Piven, Kyrylo Klymenko.

Formal analysis: Oleksandr Kubatko, Larysa Rybina.

Funding acquisition: Leonid Melnyk, Larysa Rybina.

Investigation: Vladyslav Piven, Oleksandr Kubatko, Larysa Rybina.

Methodology: Leonid Melnyk, Oleksandr Kubatko.

Project administration: Oleksandr Kubatko.

Resources: Oleksandr Kubatko.

Software: Kyrylo Klymenko, Larysa Rybina.

Supervision: Leonid Melnyk.

Validation: Kyrylo Klymenko, Larysa Rybina.

Visualization: Vladyslav Piven, Oleksandr Kubatko.

Writing - original draft: Vladyslav Piven, Leonid Melnyk.

Writing - review \& editing: Oleksandr Kubatko, Kyrylo Klymenko, Larysa Rybina.

\section{ACKNOWLEDGMENTS}

The paper contains the results of a study conducted within the framework of research projects: "Sustainable development and resource security: from disruptive technologies to digital transformation of Ukrainian economy" (No. 0121U100470); "Fundamental bases of the phase transition to an additive economy: from disruptive technologies to institutional sociologization of decisions" (No. 0121U109557). 


\section{REFERENCES}

1. Balsmeier, B., \& Woerter, M. (2019). Is this time different? How digitalization influences job creation and destruction. Research policy, 48(8), 103-112. https://doi. org/10.1016/j.respol.2019.03.010

2. Benetyte, R., Rubio, J. G., Kovalov, B., Matviychuk-Soskina, N., \& Krusinskas, R. (2021). Role of R\&D expenditure, CEO compensation and financial ratios for country's economic sustainability and innovative growth. International Journal of Global Energy Issues, 43(2-3), 228-246. https://doi.org/10.1504/ IJGEI.2021.115147

3. Bhutani, S., \& Paliwal, Y. (2015) Digitalization: a step towards sustainable development. OIDA International Journal of Sustainable Development, 8(12), 11-24. Retrieved from https:// papers.ssrn.com/sol3/papers. cfm?abstract_id $=2713132$

4. Elding, C., \& Morris, R. (2018). Digitalisation and its impact on the economy: insights from a survey of large companies. Economic Bulletin Boxes, 7. Retrieved from https:// ideas.repec.org/a/ecb/ecbbox/201800074.html

5. European Central Bank. (n.d.). ECB surveys. Retrieved from https://www.ecb.europa.eu/stats/ ecb_surveys/html/index.en.html

6. European Commission. (2021). The Digital Economy and Society Index (DESI). Retrieved from https://digital-strategy.ec.europa. $\mathrm{eu} / \mathrm{en} /$ policies/desi

7. Gebler, M., Uiterkamp, A. J. S., \& Visser, C. (2014). A global sustainability perspective on $3 \mathrm{D}$ printing technologies. Energy Policy, 74, 158-167. https://doi. org/10.1016/j.enpol.2014.08.033

8. GeSI. (n.d.). SMARTer 2030. Retrieved from http://smarter2030. gesi.org/.

9. Grytten, O. H., Lindmark, M., \& Minde, K. B. (2020). The wealth of nations and sustainable development: energy intensity and the environmental
Kuznets curve. Environmental

Economics, 11(1), 110-123.

http://dx.doi.org/10.21511/

ee.11(1).2020.10

10. Jovanović, M., Dlačić, J., \& Okanović, M. (2018). Digitalization and society's sustainable development Measures and implications. Zbornik radova Ekonomskog fakulteta u Rijeci: časopis za ekonomsku teoriju i praksu, 36(2), 905-928. http://dx.doi.org/10.18045/zbefri.2018.2.905

11. Kahouli, B. (2019). Does static and dynamic relationship between economic growth and energy consumption exist in OECD countries? Energy Reports, 5, 104-116. https://doi.org/10.1016/j. egyr.2018.12.006

12. Karintseva, O., Kharchenko, M., Boon, E. K., Derykolenko, O., Melnyk, V., \& Kobzar, O. (2021). Environmental determinants of energy-efficient transformation of national economies for sustainable development. International Journal of Global Energy Issues, 43(2-3), 262-274. https://doi. org/10.1504/ijgei.2021.115148

13. Kartanaitè, I., Kovalov, B., Kubatko, O., \& Krušinskas, R. (2021). Financial modeling trends for production companies in the context of Industry 4.0. Investment Management and Financial Innovations, 18(1), 270-284. http://dx.doi. org/10.21511/imfi.18(1).2021.23

14. Klymchuk, O., Khodakivska, O., Kovalov, B., Brusina, A., Benetyte, R., \& Momotenko, I. (2020). World trends in bioethanol and biodiesel production in the context of sustainable energy development. International Journal of Global Environmental Issues, 19(1-3), 90-108. https://doi. org/10.1504/ijgenvi.2020.114867

15. Kurbatova, T., Sotnyk, I., Baranchenko, Ye., Arakpogun, E., \& Roubik, H. (2020). State support policy for renewable energy development in emerging economies: the case of Ukraine. International Journal of Global Environmental Issues, 19(1-3),
26-52. https://doi.org/10.1504/ ijgenvi.2020.114864

16. Makarenko, I., Plastun, A., Situm, M., Serpeninova, Y., \& Sorrentino, G. (2021). Meta-analysis of the literature related to SDG 3 and its investment. Public and Municipal Finance, 10(1), 119137. http://dx.doi.org/10.21511/ pmf.10(1).2021.10

17. McKinsey \& Company. (2020). How COVID-19 has pushed companies over the technology tipping point - and transformed business forever (Report). Retrieved from https://www. mckinsey.com/business-functions/ strategy-and-corporate-finance/ our-insights/how-covid-19-haspushed-companies-over-thetechnology-tipping-point-andtransformed-business-forever

18. Melnyk, L. (2021). Socionatural antientropic potential: the role of economy and innovations. Environment, Development and Sustainability, 23(3), 3520-3542. https://doi. org/10.1007/s10668-020-00730-0

19. Melnyk, L. G., Shkarupa, E. V., \& Kharchenko, M. O. (2013). Innovative strategies to increase the economic efficiency of greening the economy. Middle East Journal of Scientific Research, 16(1), 30-37. Retrieved from https://www.idosi.org/mejsr/mejsr16(1)13/5.pdf

20. Melnyk, L., Dehtyarova, I., Kubatko, O., Karintseva, O., \& Derykolenko, A. (2019). Disruptive technologies for the transition of digital economies towards sustainability. Economic Annals-XXI, 179(9), 22-30. https:// doi.org/10.21003/ea.v179-02

21. OECD. (2019). Measuring the Digital Transformation: A Roadmap for the Future. Retrieved from https://www.oecd.org/ publications/measuringthe-digital-transformation9789264311992-en.htm

22. Price Waterhouse Coopers. (2013). Digitization for economic growth and job creation. Retrieved from https://www.strategyand.pwc. com/m1/en/reports/digitization- 
for-economic-growth-and-jobcreation.pdf

23. Rayna, T., \& Striukova, L. (2021). Assessing the effect of $3 \mathrm{D}$ printing technologies on entrepreneurship: An exploratory study. Technological Forecasting and Social Change, 164, 120483. https://doi.org/10.1016/j.techfore.2020.120483

24. Ruihui, P., Xiang, L., \& Pujiayi, Ch. (2021). Sustainable development and sharing economy: A bibliometric analysis. Problems and Perspectives in Management, 19(4), 1-19. http://dx.doi.org/10.21511/ ppm.19(4).2021.01

25. Shevchenko, H., Petrushenko, M., Burkynskyi, B., \& Khumarova, N. (2021). SDGs and the ability to manage change within the European green deal: The case of Ukraine. Problems and Perspectives in Management, 19(1), 53-67. http://dx.doi.org/10.21511/ ppm.19(1).2021.05
26. Shkarupa, O. V., Karintseva, O. I., \& Zhukova, T. A. (2017). Ecological modernization of the transport system in Sumy for green growth of economics. International Journal of Ecology and Development, 32(3), 75-85. Retrieved from http://www.ceser in/ceserp/index.php/ijed/article/ view/4982

27. Sineviciene, L., Hens, L., Kubatko, O., Melnyk, L., Dehtyarova, I., \& Fedyna, S. (2021). Socioeconomic and cultural effects of disruptive industrial technologies for sustainable development. International Journal of Global Energy Issues, 43(2-3), 284305. https://doi.org/10.1504/ ijgei.2021.10037749

28. The World Bank. (n.d.a). Digital Development. Retrieved from https://www.worldbank.org/en/ topic/digitaldevelopment

29. The World Bank. (n.d.b). World Bank Open Data. Retrieved from https://data.worldbank.org/
30. United Nations. (n.d.a).

Sustainable Development Goals. Retrieved from https://www. un.org/sustainabledevelopment/_

31. United Nations. (n.d.b). Human Development Data Center. Retrieved from http://hdr.undp. org/en/data.

32. Veklych, O., Karintseva, O., Yevdokymov, A., \& GuillamonSaorin, E. (2020). Compensation mechanism for damage from ecosystem services deterioration: Constitutive characteristic. International Journal of Global Environmental Issues, 19(1-3), 129-142. https://doi.org/10.1504/ ijgenvi.2020.114869

33. Zhang, W., Zhao, S., Wan, X., \& Yao, Y. (2021). Study on the effect of digital economy on high-quality economic development in China. PloS one, 16(9), 257-365. http:// dx.doi.org/10.1371/journal. pone.0257365 